\title{
Vasopressin V1B Receptor
}

National Cancer Institute

\section{Source}

National Cancer Institute. Vasopressin V1B Receptor. NCI Thesaurus. Code C26097.

Vasopressin V1b receptor ( $424 \mathrm{aa}, \sim 47 \mathrm{kDa}$ ) is encoded by the human AVPR1B gene.

This protein plays a role in $\mathrm{G}$ protein-coupled receptor signaling mediated by vasopressin. 